УДК 378:7.071.2(092)]:78.03.087.68(477.54-25)

DOI:

Анатолій Мартинюк, кандидат мистецтввознавства, доцент кафедри мистеизьких дисииплін і методик навчання ДВНЗ “Університет Григорія Сковороди в Переяславі"

\title{
ДИРИГЕНТСЬКА ПЕДАГОГІКА ПРОФЕСОРА А. МІРОШНІКОВОЇ У ДИНАМІЦ РОЗВИТКУ ХАРКІВСЬКОЇ ХОРОВОЇ ШКОЛИ
}

У статті розглянута диригентська педагогіка відомого педагога, творчого діяча Харківського державного університету мистецтвв імені I. Котляревського А.Мірошникової, яка посприяла розвитку харківської хорової школи. Наукове вивчення музично-педагогічного досвіду професора А. Мірошниковоі стали підтрунтям національної диригентсько-хорової освіти, формування високоморальної особистості.

Ключові слова: диригент; педагог; кониертмейстер; музичний діяч; Агнеса Мірочникова.

Лim. 8.

Anatoliy Martynyuk, Ph.D.(Art History), Associate Professor of the Artistic Disciplines and Teaching Methods Department of the

SHEI "Pereyaslav-Khmelnytskiy Hryhoriy Skovoroda State Pedagogical University"

\section{PROFESSOR A. MIROSHNYKOVA'S CONDUCTING PEDAGOGY IN THE DYNAMICS OF KHARKIV CHORAL SCHOOL'S DEVELOPMENT}

In the article it is considered the conducting pedagogy of the famous pedagogue, creative figure of $I$. Kotlyarevskiy Kharkiv State University of Arts A. Miroshnykova, who made a contribution to the development of Kharkiv Choral School. The historical bases of Kharkiv choral tradition are outlined; creation of the Department of Choral Conducting, a holistic approach to the creative and performing activity of choral compositions of Ukrainian and Western European composers as a single process of formation of the national choral tradition.

It is revealed that Agnesa Miroshnykova's artistic path is an example of the universalism of the creative personality, individual originality and unique expressiveness of each real artist. A wide range of his artistic activity is analyzed, in the aspect of revealing different vectors of the artist's creativity: performing work, pedagogical and creative activity.

Based on the analysis of scientific works of Kharkiv Choral School, it was determined that the outstanding artist attached special importance to the acquisition of knowledge, skills and abilities of conducting art. According to A. Miroshnykova, the important task of a pedagogue in the educational process is to educate the student's creative attitude to the performance of the piano part in accordance with the principles of ensemble playing; to develop practical skills that are necessary for concertmaster work, based on the knowledge acquired by a pianist in special and music-theoretical disciplines. All the necessary competencies assume the responsibility of the future specialist, who decided to dedicate himself to the conducting profession.

A. Miroshnykova's scientific researches concerning reading of choral scores, specifics of skills formation of choral scores performing are covered. It is determined that the professional skills of the outstanding choral pedagogue made a contribution to the national song traditions and provided the peculiarity of them in the modern sociocultural environment.

It is emphasized that the outstanding choral conductor and pedagogue, representative of Kharkiv Choral School Agnesa Miroshnykova is a direct active participant in the Ukrainian artistic life with high professional potential. Her creative activity contributes to the development and formation of the modern context of the spiritual life of Kharkiv Choral School and Ukraine in general.

Summarizing the mentioned above, we should note that the scientific research of Professor A. Miroshnykova's pedagogical experience became the basis of national conducting and choral education, the formation of a high moral personality. Agnesa Miroshnykova's conducting pedagogy is recognized as a significant contribution to the development of Kharkiv Choral School, as well as Ukrainian culture.

Keywords: a conductor; a pedagogue; concertmaster; Kharkiv Choral School; Agnesa Miroshnykova.

П остановка проблеми. 3 архівних джерел відомо, що становлення Харківської диригентсько-хорової школи пов'язане з діяльністю кафедри хорового диригування ХДУМ ім. І.П. Котляревського, фундаторами якої стали О. Перунов, К. Греченко,
3. Заграничний. Створення кафедри хорового диригування відповідало вимогам часу - постала нагальна потреба у кваліфікованих, професійно підготовлених хорових диригентах, які б сприяли виконанню не тільки масових пісень, а й пропагували своєю діяльністю кращі зразки 


\section{ДИРИГЕНТСЬКА ПЕДАГОГІКА ПРОФЕСОРА А. МІРОШНІКОВОЇ У ДИНАМШІ РОЗВИТКУ ХАРКІВСЬКОӤ ХОРОВОЇ ШКОЛИ}

світової класики, відроджували вітчизняні традиції хорового мистецтва [1,117-122].

Аналіз останніх досліджень і публікацій. В питаннях обраної проблематики ми спиралися на роботи таких науковців як О. Батовська, Н. БєлікЗолотарьова, С. Прокопов, Г. Савєльєва, Н. Шумакова та ін. Аналізуючи останні наукові праці українських дослідників Харківської диригентськохорової школи, переконуємося у більш об'єктивному та повноцінному висвітленні науковцями картини їі історичного розвитку.

Отже, метою статті висвітлення диригентської педагогіки А. Мірошникової у динаміці розвитку Харківської хорової школи.

Виклад основного матеріалу. Важко переоцінити надзвичайно плідну мистецьку діяльність як хорового диригента і педагога А. Мірошникової, яка стала важливим джерелом формування Харківської хорової школи.

Вроджений музичний хист майбутнього митця розкрився в ранньому дитинстві. Музичне обдарування вона успадкувала від своїх батьків, тата - Анатолія Сергійовича і мами - Фаїни Андріївни, які опікувалися художнім розвитком своїх дітей - доньки і сина. В батьківському домі постійно лунали музика і співи. У музичній школі №1 виняткові музичні здібності дівчини привернули увагу відомих митців і педагогів по класу фортепіано Р. Рогозіної (випускниці Петербурзької консерваторії), і хорового класу €. Конопльової (випускниці Харківської консерваторії), згодом головного хормейстера Харківського оперного театру і професора Харківського інституту культури. Музичне обдарування А. Мірошникової розкрилося надзвичайно багатогранно під час навчання в Харківському музичному училищі, яке вона закінчила екстерном за двома спеціальностями: як піаністка і як хоровий диригент. Така багатовекторність щодо осягнення музичного мистецтва простежується у неї і в наступні роки, коли вона навчається в Харківській консерваторії спочатку на фортепіанному (клас професора Л. Фаненштіля), а далі на диригентському факультеті (клас професора К. Греченка).

Важливою віхою в житті А. Мірошникової було навчання в аспірантурі Київської консерваторії, де iii науковим керівником був завідувач кафедри хорового диригування професор М. Вериківський. Як вона згадувала справжнім подарунком долі стали для неї ті роки, коли вона спілкувалася 3 видатними музикантами, передусім з диригентами Н. Рахліним, К. Сімеоновим і В. Тольбою, які в той час працювали в оперній студії консерваторії. Заключним етапом навчання був виступ аспірантки як диригента 3 хоровою капелою “Думка" та симфонічним оркестром оперної студії. До концертної програми увійшли твори К. Стеценка та інших українських композиторів. Відбувся також успішний захист ії кандидатської дисертації на тему“Хорова творчість Кирила Стеценка". Після завершення навчання А. Мірошникова розпочинає працю в консерваторії концертмейстером оперної студії, де отримала цінний досвід щодо осягнення хорового виконавства.

У музичній культурі України другої половини XX - початку XXI ст. А. Мірошникова - визначна творча Особистість, якій були притаманні широта гуманітарного світогляду, висока диригентська, вокальна та піаністична майстерність, енциклопедична музична освіченість, глибина музичного мислення, надзвичайно тонке відчуття образності, драматургії, жанрової і стильової природи музики, винятковий організаторський хист, вроджений дар педагога та чудові людські якості.

Диригентська педагогіка стала справою всього життя професора А. Мірошникової. На кафедрі хорового диригування Харківської консерваторії ім. І. Котляревського вона викладала широке коло навчальних дисциплін, а саме: диригування, читання хорових партитур, хорознавство, хорова література, методика викладання хорових дисциплін. Кожна із них позначена новими рисами і віддзеркалювала великий художній талант, глибину знань і багатогранність особистості професора.

Педагогічне кредо А. Мірошникової розкривалося 3 найбільшою повнотою у їі диригентському класі, основним спрямуванням якого було формування неповторної творчої індивідуальності хорового диригента, розвиток його музичного мислення, осягнення усього розмаїття диригентської техніки, диригентське втілення хорової музики різних стилів і жанрів. Ïї педагогічну працю вирізняє цілісний підхід до вивчення хорової музики, невід'ємними складовими якого є гра твору на фортепіано; спів партій; музично-виконавський аналіз образності і музичної драматургії твору; пошуки таких засобів диригентської виразності, які найбільш повно відображають художню ідею твору, його жанрові ознаки і музичну стилістику [8].

А. Мірошникову вирізняє особливий дар відчути індивідуальність учня та розвинути в ньому найкращі риси. Окремі їі учні стали не тільки хоровими, а й симфонічними диригентами. До цієї генерації відомих митців належить Ю. Янко. Ще під час навчання в Харківській музичній школі десятирічці професор помітила його інтерес до 


\section{ДИРИГЕНТСЬКАПЕДАГОГІКАПРОФЕСОРА А. МІРОШНІКОВОЇ}

У ДИНАМІЦІ РОЗВИТКУ ХАРКІВСЬКОӤ ХОРОВОЇ ШКОЛИ

оркестрового диригування. У зв'язку з цим були внесенні певні корективи до змісту навчання. Відбувалося вивчення не лише хорової, а й інструментальної музики. Інструментальний компонент у хорових композиціях отримував глибоке осмислення в його уявній проекції на оркестрове звучання і виразне відтворення диригентським жестом.

Низку цінних думок містять спогади професора С. Прокопова, який окреслює ¥ї диригентську педагогіку: “Диригентську педагогіку професора А. Мірошникової вирізняють такі ознаки: спрямованість на розвиток у студентів уміння перетворювати свої музичні уявлення та жести за допомогою пластичних рук і набуття вміння впливу на художній колектив через диригентські жести; досягнення скоординованих дій усіх частин диригентського апарату; поступове наповнення диригентських рухів образними та змістовними елементами; комплексне осягнення образної сфери і музичної драматургії твору як підгрунтя для створення необхідної моделі його диригентського втілення" [5, 9-12.]. Формування не лише хорового а й оркестрового мислення студентів стало однією із визначальних рис диригентської педагогіки А. Мірошникової.

У діяльності музичного закладу освіти вагоме місце належить піаністові-концертмейстеру. Удосконалення особливих професійних якостей піаністів, необхідних для концертмейстерської роботи, відбувається на фортепіанних факультетах вищих мистецьких закладів освіти. Виняткову роль у цьому контексті відіграє концертмейстерський клас. Проблематика цієї навчальної дисципліни розкривається в методичних рекомендаціях А. Мірошникової "Про роботу концертмейстера в класі хорового диригування" [3]. Автор праці висловлює думку, що “головне завдання педагога полягає в тому, щоб виховати у студента творче відношення до виконання фортепіанної партії у відповідності з принципами ансамблевої гри; розвивати практичні навички, необхідні для концертмейстерської роботи, спираючись на знання, набуті піаністом зі спеціальних і музичнотеоретичних дисциплін” $[3,3]$.

Зміст навчальної програми спрямований на підготовку студента до співпраці з вокалістами, вивчення вокальної музики. Студент отримує відомості про класифікацію співацьких голосів, їх діапазон, теситуру, рухливість, виразність, про співацьке дихання, дикцію, висвітлюється питання щодо синтезу музичного та літературного тексту.

Важливим розділом навчальної програми концертмейстерського класу є вивчення оперної музики. У системі професійних компетентностей піаніста-концертмейстера цінною рисою є уміння поєднати у виконанні фортепіанну партію й вокальнохорову партитуру [6]. Оперні сцени можуть виконуватися в класі двома піаністами. Один із них відтворює вокально-хорову партитуру, інший інструментальний супровід. Таке виконання дає змогу найбільш повно охопити музичну фактуру твору; поглибити слухові уявлення про його образний стрій і музичну драматургію; набути більшого досвіду гри в ансамблі; наблизити навчальний процес до умов практичної діяльності концертмейстера в диригентському класі.

Творча діяльність концертмейстера класу хорового диригування, а також концертмейстера в оперному театрі, потребує високого рівня професійної майстерності та наявності глибоких і різнобічних знань. Формування такої особистості відбувається у музичній академії та університеті в процесі вивчення широкого циклу гуманітарних, музично-теоретичних і музично-виконавських дисциплін. Цілеспрямована підготовка музиканта відбувається у концертмейстерському класі. Виняткове значення має також систематичне самостійне опрацювання студентом низки навчальних завдань.

Таким чином, під час навчання створюються передумови для визначення профілю майбутньої творчої діяльності студента і відбувається формування важливих для музиканта навичок i професійних компетентностей:

- високий рівень музичного мислення, здатність музичного слуху цілісно охоплювати різні фактурні елементи хорового твору в його горизонтальному та вертикальному вимірах;

- тонке відчуття музики, уміння узгоджувати свої дії з іншими виконавцями; швидка реакція і перехід від одного емоційного стану до іншого;

- відтворення на фортепіано такого розмаїття тембральних барв, яке віддзеркалює звучання різних інструментів і типів співацьких голосів;

- осмислення артикуляції, усвідомлення агогічних змін, пов'язаних $з$ логікою побудови музичного фразування;

- розуміння диригентського жесту, розвиток диференційованої уваги;

- наявність творчої ініціативи, виявлення самостійності у вирішенні художніх завдань [7].

Навчальна програма концертмейстерського класу студентів фортепіанних факультетів музичних академій та університетів містить такий важливий розділ, як розвиток читання хорових партитур. Це обумовлено спрямуванням практичної діяльності музикантів, які причетні до хорового мистецтва. Воно передбачає оволодіння різними специфічними навичками, такими як 


\section{ДИРИГЕНТСЬКА ПЕДАГОГІКАПРОФЕСОРА А. МІРОШНІКОВОЇ}

\section{У ДИНАМШЦ РОЗВИТКУ ХАРКІВСЬКОӤ ХОРОВОЇ ШКОЛИ}

читання хорових творів без супроводу, уміння об'єднати у виконанні фортепіанну партію i вокально-хорову партитуру, узгоджувати свою гру 3 інтерпретацією диригента. Ці та інші питання розкриваються в методичних рекомендаціях А. Мірошникової "Читання хорових партитур в концертмейстерському класі” [4].

Автор праці характеризує особливості запису хорової партитури. На відміну від звичного дворядкового запису фортепіанної музики, вона може містити різну кількість стрічок. Це випливає 3 типу, виду хору, а також складу хорових партій. Групування нот у хоровій музиці також має свої відмінності і пов'язане зі складами літературного тексту. Відтворення нотного тексту, особливо в речитативах, ускладнюється відсутністю групування нот у запису. В таких випадках необхідно виявити логічні наголоси в тексті та зробити уявне групування тривалостей. Вокально-хорова музика має свої відмінності щодо фразування. Воно визначається змістом літературного тексту, а тому фразировочні ліги не виставляються. У хоровій музиці, на відміну від інструментальної, не виставляються також ліги для позначення зв'язного виконання.

Формування навичок виконання хорових партитур доцільно розпочинати з вивчення хорових творів гармонічного складу. Визначальною ознакою виконання таких творів $\epsilon$ рівноцінна звукова наповненість кожного акорду, з деяким динамічним виділенням верхнього та нижнього голосів, що віддзеркалює реальне хорове звучання. Співвіднесеність сили звуку мелодії і гармонічного фону є визначальною рисою виконання творів гомофонно-гармонічного складу. Вивчення хорової поліфонії передбачає наявність уміння чути горизонтальний рух кожного голосу.

Професор А. Мірошникова стверджує, що “При виконанні хорової поліфонічної тканини необхідно передати фразування, виконавський штрих, динаміку, зміну дихання, темброву характеристику кожної хорової партії. I в кінцевому рахунку, розмаїття виконавських деталей не повинні перешкоджати досягненню єдиної, безперервної лінії розвитку художнього образу, розбудові співвідношень кульмінаційних вершин, сприяти цілісності виконання" $[4,7]$.

Науково-методична праця містить низку думок стосовно виконання таких хорових творів без супроводу, в яких використано мішаний тип фактури. Наводяться окремі міркування стосовно диригентського прочитання хорового твору Б. Лятошинського на вірші Т. Шевченка "Тече вода в синє море", який став класикою національної хорової музики ХХ ст.
Професор А. Мірошникова стверджує, що важливим аспектом вивчення хорової партитури $\epsilon$ прослуховування його музичної тканини по горизонталі, що створює підгрунтя для встановлення динамічного співвідношення різних елементів фактури та виявлення їхньої змістової наповненості. Ознайомлення з тим, як звучить цей твір у живому виконанні хору, або хоча б у запису, допоможе найбільш повно зрозуміти природу хорового письма, відчути наповненість співацьких дій при відтворенні різної теситури, характер звуковидобування, своєрідність тембрового забарвлення кожної хорової партії. Виконання хорового твору на фортепіано буде вирізнятися справжньою глибиною осягнення його ідеї та музичної стилістики, коли студент уявно проспівує текст і прагне відтворити в своїй уяві тембр хорових голосів та всі деталі інтерпретації.

Глибиною музикознавчої думки вирізняється наукова розвідка А. Мірошникової “Кирил Стеценко як хоровий диригент" [2, 215-221]. У них уперше розкривається феномен диригентськохорової діяльності композитора, творчого діяча К. Стеценка, в якій тонкою лінією простежується невід'ємний зв'язок з традиціями музичного мистецтва М. Лисенко. Цілісність музичної культури, плідна взаємодія композиторської, музикознавчої та музично-виконавської школи стала провідною думкою для видатного українського композитора. Такий універсалізм був притаманний фундаторові української класики М. Лисенку, а також його учням і послідовникам. Серед них, такі знакові постаті національної музичної культури ХХ ст., якК. Стеценко, М. Леонтович, О. Кошиць, С. Людкевич, Я. Яциневич, М. Колесса та ін.

Автор наукового дослідження, професор А. Мірошникова відтворює постать К. Стеценка як диригента і висловлює думку про те, що “взагалі Стеценко належав до тих диригентів, які вміли пробудити у співаків активне ставлення до співу, бажання глибоко проникнути у зміст виконуваного твору. Пояснюючи кожну музичну фразу, він намагався розбудити його уяву, малюючи яскраві картини та образи" [2, 220]. Його диригентські рухи були енергійними й переконливими, хоч і гранично скромними. Надзвичайно виразним було обличчя і погляд очей, які віддзеркалювали усі зміни виконання.

У процесі розучування твору композитор часто звертався до скрипки, флейти, фісгармонії, на який відтворював основний інтонаційно-тематичний матеріал. Використання музичного інструменту було мінімальним в роботі 3 професійними хоровими колективами. Іноді диригент 


\section{ДИРИГЕНТСЬКАПЕДАГОГІКАПРОФЕСОРА А. МІРОШННКОВОЇ У ДИНАМШЦ РОЗВИТКУ ХАРКІВСЬКОЇ ХОРОВОЇ ШКОЛИ}

підтримував на інструменті лише гармонічну основу твору. За таких умов більш усвідомлено відбувалося досягнення чистоти строю i злагодженості ансамблю артистами хору. Особливо виразно в інтерпретації Кирила Стеценка звучали ліричні твори.

Таким чином, опрацювання широкого кола архівних матеріалів дало змогу А. Мірошниковій висвітлити подвижницьку працю К. Стеценка на теренах хорового виконавства та педагогіки як визначне явище національної музичної культури.

Висновки та перспективи подальших наукових розвідок. Комплексний та всебічний аналіз мистецької та педагогічної діяльності А. Мірошникової надасть можливість простежити та виявити різні аспекти творчої актуалізації митця. Ї̈̈ мистецька та педагогічна діяльність набуває неабиякого значення у контексті розбудови харківської диригентсько- хорової школи. Результати, отримані в процесі аналізу мистецької тапедагогічної діяльності А. Мірошникової, можуть бути використані в монографічних й публіцистичних публікаціях, а також у педагогічній практиці, зокрема в курсах навчальних дисциплін закладів середньої та вищої освіти.

Перспективою подальшого розгляду досліджуваної проблеми передбачають конкретизацію педагогічних умов диригентської педагогіки А. Мірошникової, дотримання яких забезпечуватиме основи духовно-творчого розвитку майбутнього фахівця.

\section{ЛІТЕРАТУРА}

1. Бєлік-Золотарьова Н.А. Майстри Харківської диригентсько-хорової школи (До 90-річчя Харківського державного університету мистецтв ім. І.П.Котляревського) Актуальні проблеми мистецької практики $i$ мистецтвознавчої науки “Мистецькі обрії”. Вип. 1(10). Київ: “Музична Україна” 2008. С.117-122.

2. Мірошникова А.А. К.Г. Стеценко як хоровий диригент. Українське музикознавство. Вип. 3. Київ. 1968. С.215-221.

3. Мирошникова А. О работе концертмейстера в классе хорового дирижирования: Методические рекомендации для преподавателей и студентов музыкальных вузов. Киев, 1990.20 с.

4. Мирошникова А.А. Чтение хоровых партитур в концертмейстерском классе. Методические рекомендации по курсу "Концертмейстерский класс”. Харьков. 1988.

5. Прокопов С.М. Робота над пластичністю жесту в класі хорового диригування. Диригентсько-хорова освіта: синтез теорії та практики: матер. III всеукр. наук.практ. конф., 31 жовтня 2019p. під ред. проф. БелікЗолотарьової Н.А. та доц. Батовської О.М. Харків: ТОВ "Планета-Прінт" 2019. С. 9-12.

6. Савельєва Г.В. Виконавські традиції харківської хорової школи: дис. ... канд. мистецтвозн.: 17.00.03. Харків, 2012.276 с.
7. Харківський державний університет мистецтв імені І.П. Котляревського Pro Domo Mea: Нариси. До 90-річчя з дня заснування Харківського державного університету мистеитв імені І.П. Котляревського / Ред. Т.Б. Вєркіна, Г.А. Абаджян, Г.Я. Ботунова та ін. Харків, 2007.336 c.

8. Шумакова Н.М. Очерк о жизни и деятельности Агнессы Анатольевны Мирошниковой. Харьков, Финарт, 2008. 44 с.

\section{REFERENCES}

1. Belik-Zolotareva, N. (2008). Maistry Kharkivskoi dyryhentsko-khorovoi shkoly (Do 90-richchia Kharkivskoho derzhavnoho universytetu mystetstv im. I.P.Kotliarevskoho). [Masters of Kharkiv School of Conducting and Choir (To the 90th anniversary of Kharkiv State University of Arts named after IP Kotlyarevsky)]. Current issues of art practice and art history "Art Horizons". issue 1 (10). Kyiv, pp.117 - 122. [in Ukrainian].

2. Miroshnikova, A. (1968). K.H. Stetsenko yak khorovyi dyryhent [K.G. Stetsenko as a choral conductor] Ukrainian musicology. Vol. 3. Kyiv, pp.215-221. [in Ukrainian]

3. Miroshnikova, A. (1990). O rabote kontsertmeystera $\mathrm{v}$ klasse khorovogo dirizhirovaniya [About the work of the accompanist in the class of choral conducting] Methodical recommendations for teachers and students of music universities. Kyiv, 20 p. [in Russian].

4. Miroshnikova, A. (1988). Chtenie khorovykh partitur $\mathrm{v}$ kontsertmeysterskom klasse [Reading choral scores in an accompanist class]. Methodical recommendations for the course "Concertmaster class". Kharkiv. [in Russian].

5. Prokopov, S. (2019). Robota nad plastychnistiu zhestu v klasi khorovoho dyryhuvannia [Work on the plasticity of gesture in the class of choral conducting] Dyryhentsko-khorova osvita: syntez teorii ta praktyky: mater. III vseukr. nauk.-prakt. konf., 31 zhovtnia 2019 r.Conducting and choral education: a synthesis of theory and practice: Proceedings III All-Ukrainian ScientificPractical Conference, October 31, 2019. (Ed.). BelikZolotareva N. and Batovska O., (pp. 9-12). Kharkiv. [in Ukrainian].

6. Savelieva, G. (2012). Vykonavski tradytsii kharkivskoi khorovoi shkoly [Performing traditions of the Kharkiv choral school]. Candidate's thesis. Kharkiv, 276 p. [in Ukrainian].

7. Kharkivskyi derzhavnyi universytet mystetstv imeni I.P. Kotliarevskoho Pro Domo Mea [Kharkiv State University of Arts named after I.P. Kotlyarevsky Pro Domo Mea]. Essays. To the 90th anniversary of the founding of Kharkiv State University of Arts named after I.P. Kotlyarevsky. (2007). (Ed.). T. Verkina, G. Abadjan, G. Botunova and others. Kharkiv state University of Arts named after I.P.Kotlyarevsky. 336 p. [in Ukrainian]

8. Shumakova, N. (2008). Ocherk o zhizni i deyatelnosti Agnessy Anatolevny Miroshnikovoy [Essay on the life and work of Agnessa Anatolyevna Miroshnikova] Kharkiv, 44 p. [in Russian].

Стаття надійшла до редакції 07.10.2020 